\title{
CREATORS, RESEARCHERS AND USERS OF \\ INTANGIBLE CULTURAL HERITAGE IN THE LIGHT \\ OF THE NATIONAL LIST OF LIVING CULTURAL \\ HERITAGE
}

NAŠKO KRIŽNAR

The drafting of the national list of intangible cultural heritage is a great challenge for the ethnological methodology for the study of cultural heritage. The author focuses on the significance of the triangle that links creators, researchers and users of cultural heritage; this can aid in the redefinition of the role of cultural heritage in science and in society.

Keywords: intangible cultural heritage, ethnology, UNESCO Convention on the Safeguarding of the Intangible Cultural Heritage, system of intangible culture.
Izdelava nacionalnega seznama nesnovne kulturne dediščine je velik izziv za etnološko metodologijo preučevanja kulturne dedišcine. Avtor usmerja pozornost na pomen trikotnika, ki povezuje ustvarjalce, raziskovalce in uporabnike kulturne dedišcine; ta lahko na novo definira vlogo kulturne dedišcine $v$ znanosti in $v$ družbi.

Ključne besede: nesnovna kulturna dedišcina, etnologija, Unescova Konvencija o varovanju nesnovne kulturne dedišcine, sistem nesnovne kulture.

All that is does not fade (Nič, kar je, ne mine)

(Uroš Zupan, 2011)

I.

When the summaries of the papers of our conference were printed, I added the words of Uroš Zupan to the introduction of my presentation: "All that is does not fade." These verses and the entire philosophy that stands behind them can be a good starting point for thinking about the basic features of contemporary interest in cultural heritage. The UNESCO Convention on the Safeguarding of the Intangible Cultural Heritage (2003) questioned many past approaches and opened a new perspective on the field of cultural heritage. Never before was it so clear that cultural heritage is an issue with many shareholders and that we must search for its meaning within the triangle creator-researcher-user of cultural heritage. This means that we are speaking about the fundamental integration of cultural heritage into the social fabric. For this reason it is important that in the process of studying cultural heritage we focus on the question of motivation on the part of all three sides of the triangle.

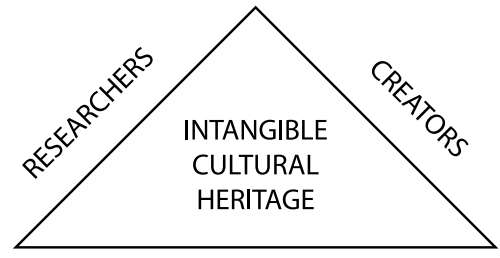

USERS 
In the past, ethnological research on cultural heritage or, as we called it then, folk/popular culture - if with this term we referred to culture as a way of life, an integral part of which was also cultural heritage - it was important to know how certain forms of heritage came to be (genesis) and how they fit into the overall image of folk culture (structure). Researchers were those who were predominantly interested in these questions, in the best of cases the so-called public of specialists composed of researchers of culture (ethnologists, anthropologists, sociologists and geographers, etc.) as well as employees of the public sector in addition to interested representatives of society understood more broadly. Today it is important to keep in mind how different genres of culture can be integrated into contemporary life; we are especially interested in knowing what these genres mean to contemporary actors at the local and national level. Their activities are the basis for the development of our assessment of the meaning and significance of cultural heritage. For this reason the interest of researchers has once again turned, stronger than ever, to the creators of heritage, to singers, dancers, artisans, storytellers, and other exponents, to the organizers and performers of rituals and to those that transmit/pass on traditional knowledge about mythology, nature, and the universe. Without them there is no intangible heritage, for intangible heritage is not something static or unchanging but is live material to which heritage creators of every age add something new while at the same time they are the first in line to pass these skills and knowledge on to their descendants. Moreover, they are the first in line in the understanding, safeguarding and interpretation of intangible heritage. We can find the basis for this particular understanding of the relationship between creators and researchers of cultural heritage in the articles of the UNESCO Convention on the Safeguarding of the ICH itself, particularly in Article 15, as well as implicitly in other convention articles.

However, once can still come across researchers that cannot or will not accept the new status that the pertinent disciplines have in the research of intangible cultural heritage. Some simply taking the elements of cultural heritage into their own hands as usual, they consider these elements without making allowances for the bearers or creators of heritage and they declare their insights as their own discoveries. In this way, they wish to maintain their dominant status within the mentioned triangle instead of politely stepping aside and recognizing the other two sides of the triangle and contributions they have to provide to the bigger picture, their responsibilities to the development, survival and preservation of cultural elements. Researchers cannot assume exclusive rights to the interpretation of cultural heritage while demanding from the creators of heritage that they obediently accept our explanations and advice, given that "We know more what this and that means", "You are only the performers (of rituals, of crafts, of songs, of dances, etc.)", "Be careful that you won't do something wrong!"

It is however also the case that only ethnology has developed in the field of cultural heritage research working methods that are based on a good measure of empathy based on a familiarity of the state of frame of mind of fellow human beings. For this reason it is the 
discipline most often called to lead procedures for drafting the live cultural heritage list. However I would recommend to all who are involved in the study of intangible heritage to approach this issue with the largest amount of empathy possible and with a great deal less authoritativeness than has been normally used in previous eras of ethnology. An emic and reflexive research approach should decrease the dominance of one-sided explanations of culture. Let things unfold as they unfold, let us try to understand them and reflect upon them without developing scales of value in accordance with our own criteria and systems. Let us identify with the soul of the creators of intangible heritage and help that the most creative impulses and people who stand behind them express themselves and come into play. "In contrast with tangible heritage protected in the museum, intangible heritage consists of cultural manifestations (knowledge, skills, performance) that are inextricably linked to persons" (Kirshenblatt-Gimblett 2004: 60).

II.

Let us go now to the other side of the triangle, to the creators of heritage. Here there is a considerable amount of confusion. Misunderstandings arise due to the lack of information on the part of those who propose heritage elements as to what the Convention on the Safeguarding of $\mathrm{ICH}$ can provide as well as mistaken expectations concerning what intangible heritage is. (By the way: one of the most important roles of the researchers in this context is explaining to people what the Convention on the Safeguarding of ICH and law understanding/define as intangible heritage and what the national list represents - in short, that they shed light on the criteria in accordance to which elements of intangible heritage are chosen and registered on the list!)

Let us see where misunderstandings arise. They are most apparent in the proposals for the national list that were made by creators of intangible heritage that we received during the period when we fulfilled the role of coordinating the safeguarding of live cultural heritage. Here is an example: People speak with nostalgia about the past and then someone in a particular place has the idea to revive how in the past they used to haul hay from the mountain pastures in improvised sleds. This idea for revival is encouraged by reports and invitations concerning the formation of the national register. People begin to feel competitive or wish that their village will also make it onto the register. While the hauling of hay from the mountain pastures represents only a (small) part of the main livelihood of the villagers - which was animal husbandry - in the eyes of the villagers the hauling of hay becomes a symbol of this livelihood that they have elevated to the level of cultural heritage of the village. Pars pro toto! Technically speaking it is not possible to understand the hauling of hay without taking into account the entire cultural context, in this case the year of animal husbandry, which of course cannot be revived in its entirety. 


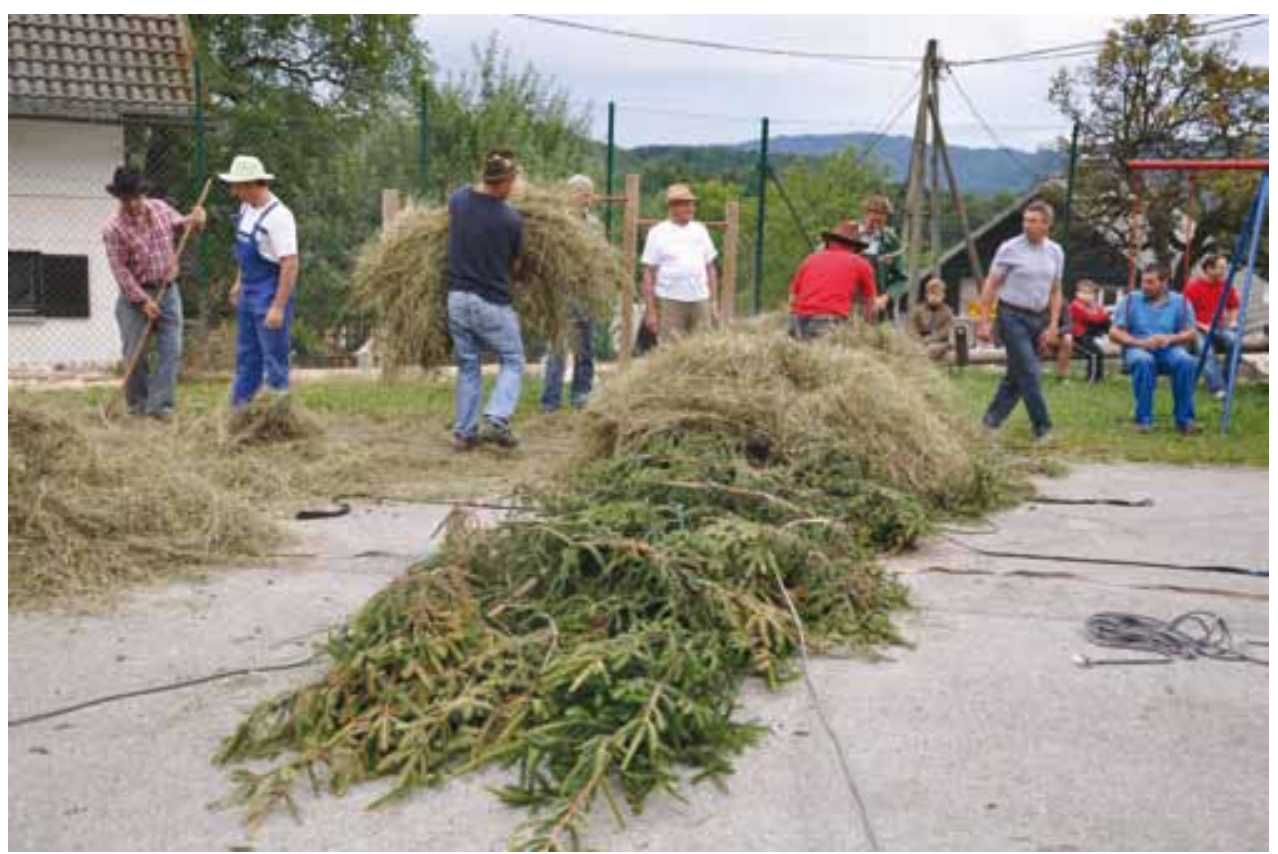

Figure 1. Reconstruction of the production of the "train" for pulling hay. On the school playground as part of the Harvest Festival celebrations (photo: N. Križnar).

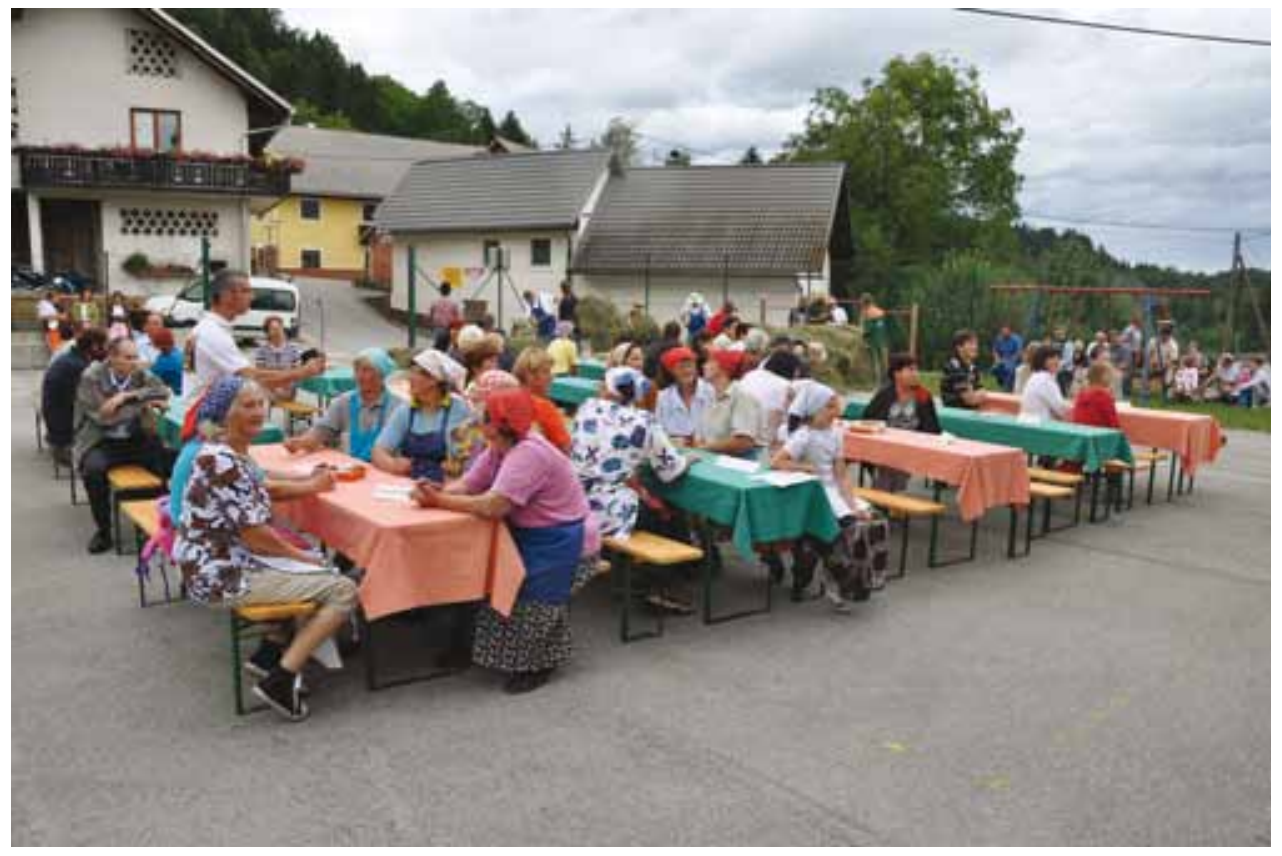

Figure 2. Harvesters at the banquet after the completed demonstration of the harvest, as part of the Harvest festival celebrations (photo: N. Križnar). 
I have not brought up this case in order to belittle or make fun of the above-mentioned activity. On the contrary, I respect all the different processes of cultural heritage construction on the basis of real cultural elements, even if at first glance they may seem absurd. I simply wish to point out that in this case we can identify a common motive for the artificial revival of cultural elements. The fact of the matter is that nowadays a great deal of intangible heritage is staged. We can even speak of the difference between lived and staged elements of cultural heritage. The authentic or lived is linked to just a few individuals or groups that perform in the old cultural way for themselves or for a smaller group. They do not expect observers, promotion, fame, or money. Less authentic are events or activities that are staged by individuals or groups in order to invite the largest number of observers possible in order to invite attention, media popularity or awards. To this end the cultural element is often staged, even outside traditionally defined space and time.

One may complement this classification of forms (presentations/performances) of cultural heritage with the words of philosopher Nelson Goodman, who makes a distinction between two sorts of phenomena. One class of manifestations of cultural heritage may be termed "autographic", and this term refers to those phenomena or manifestations for which the material and product are one and the same, such as pictures, sculptures, pottery, etc. The second class of phenomena are "allographic", in the case of which the material and product are not one and the same, such as music, dance, theater, all such phenomena that involve numerous persons performing in accordance with the same plan or pattern (Margolis 1981).

When cultural activities are not longer lived but staged, we come to the realization that intangible or cultural heritage is not only a technical or cultural issue but also a political and economic one. Numerous activities on the part of creators and users in the field of intangible cultural heritage thus contain political and economic dimensions and motivations in addition to cultural ones.

III.

Politics thus can be not only a user but also client of the intangible heritage register project. The Convention on the Safeguarding of ICH was signed by the state at the highest level and in this way the state committed itself to resolving all issues linked to intangible heritage as they are defined by the Convention. For this reason all activities associated with intangible heritage are placed in the context of government ministries, in particular cultural agencies or bodies that are established for this specific purpose. In such an environment the idea of promoting the state by way of registration in the representative UNESCO list soon arises, incited by the competitiveness of other states in this field. However, the question is how this issue affects careful reflection on the nature and significance of intangible heritage in a particular country, especially as it concerns the realization of the true spirit of the Convention as well as the benefits for heritage creators. "Some fear the power of state agencies 
and the possible national control of traditional cultural expression, often in the form of top-down interventions that are not necessarily based on the criteria of those persons who are the bearers of certain elements of intangible heritage" (Nikočević 2003: 67).

The economic benefit of activities in the field of intangible heritage is a legitimate issue both for the creators of cultural heritage as well as for its managers. These issues are dealt with separately from the register, although sometimes they are also resolved in conjunction with the register. It is clear that the desire for profit motivates numerous actors in the field of intangible heritage. Most often it is the managers of heritage who wish to capitalize on heritage in various ways. Staging heritage for touristic purposes is nowadays the dominant motto for numerous local communities as well as developmental or touristic organizations. However, in these cases I would not employ the often-used term commercialization, which has negative connotations; instead I propose using the term utilitarian valuation of cultural heritage, which is a common occurrence in our case. I see the danger in this sort of valuation in the development of a mistaken assumption that in the contemporary world, the only valid elements of intangible cultural heritage are those that are "useful" as other products in the consumer segment of society. This encourages the bearers of heritage to organize their activities in the forms of standard corporate activities including mass production, marketing and the creation of media images.

The same case is with the predicate "ethno". As is the case elsewhere in the developed world, so-called ethno culture is very popular - for example in music, cuisine, in architecture and especially in all fields in which it is possible to market cultural heritage. The predicate "ethno" is normally employed as a sign that the creators draw inspiration from "authentic", "traditional" culture that has been modernized to cater to the taste of modern users.

One can identify the varied manifestations of organized efforts for the greatest inclusion possible of elements of intangible heritage into modern life. In Slovenia, there is an established system of professional evaluation and selection of home-made and artistic crafts as well as typical national foods. The Chamber of Crafts of Slovenia publishes a list of craftsmen who have been given a license for the production of objects from the field of cultural heritage and have in this way obliged themselves to continue production in accordance to specific criteria. ${ }^{1}$

Professionally substantiated activities often become the icons of local cultural heritage, which is positive from the point of view of a greater respect for heritage skills and knowledge on the part of people and local authorities. However, this can have also negative consequences if the entire sphere of cultural heritage in certain places and municipalities is neglected because of the amount of attention focused of publicly exposed cultural elements.

1 See: http://www.podezelje.com/, especially, for example, Pletarstvo Kolšek (http://www.rokodelstvo.si/ index.aspx), or Nada Cvitkovič (http://www.zkds.si/?q=node/56), that deals with the same cultural elements, althought they are presented in a different context. 


\section{CONCLUDING THOUGHTS}

Allow me in my conclusion to return to Uroš Zupan. What did this poet wish to tell us in his verses that frame the entire collection of poems titled The Shape of Paradise? "All that is does not fade!" In his poems he returned to his childhood and described his feelings at that time, realizing that those feelings will always remain with him and that they are written into his being even if the material basis of childhood disappeared long ago.

There is an approximately 2000 year-old wooden shrine in the Japanese town of Ise Jing. Every twenty years, they rebuild the shrine in such a way that they faithfully preserve the basic shape of the temple. The ritual Shikinen sengu that lasts eight years is carried out as an accompaniment to all the phases of the construction and consecration of the temple. Whole groups of craftsmen, each for a particular part of the temple, gather to carry out the renovation and pass the skills of wooden construction without nails to the next generation. The knowledge of the temple construction is 2000 years old, while the last version of the temple is always at most 20 years old.

In Slovenian ethnology, the concept of cultural heritage is considered in a range of ways that in turn do not address so much the nature of cultural heritage itself but reflect on the range of ways that researchers relate to it. Generally speaking, one could argue that the relationship that Slovene researchers have with the concept of cultural heritage is ambivalent. In recent years, the concept of cultural heritage has not been questioned. It referred to the content of so-called popular, or folk, culture that has a unique feature: that as an essence in the form of behavioral patterns or especially as intangible elements of culture is permanently embedded in the ways of life of numerous generations of members of a particular ethnicity, people or nation. This is the root of property as the synomym of "heritage": that which heirs receive from their parents after their death. In more recent times, when in the field of ethnology they were redrafting the epistemological questions of the discipline (typical postmodern self-questioning), the attention of researchers was directed more at synchronic webs of phenomena instead of at their genesis, the concept/ phenomenon of cultural heritage once again became terminologically questionable and also the object of ethnological study.

The project of the Slovenian intangible heritage register could be understood as the basis for a common understanding of cultural heritage regardless of the varied epistemological foundations. Today cultural heritage is no longer an eminent subject of epistemological study, nor is it a tool or weapon for national defense. Today cultural heritage in the global sense of the term is recognized as a "blue chip" of the countries acceeding to the Convention for the Safeguarding of the ICH. Its significance does not depend solely upon the view of researchers but also upon the motivation and opinion of its creators and implementors. Never before has cultural heritage so obviously represented a theme "par excellence" for the humanistic disciplines - especially for ethnology - as well as an opportunity for reflection upon the new methodological foundations for the study of cultural heritage. It represents 
as well an opportunity for the unanimous restructuring of a broader social relationship with cultural heritage as a key state subsystem of culture. This leads us to other UNESCO conventions, including, for example, the Universal Declaration of Cultural Diversity (2001) as well as the Convention on the Protection and Promotion of Cultural Expression (2005), both of which significantly complement the Convention for the Safeguarding of the ICH and accord it a broader significance that that of the national register and the UNESCO Representative List. And perhaps it is not useless to presume that a consideration of all three Conventions, and of empathic treatment of cultural heritage could lead to the democratic ethics in culture research.

\section{REFERENCES}

Kirshenblatt-Gimblett, Barbara

2004 Intangible Heritage as Metacultural Production. Museum International 56 (1-2): 52-65.

Margolis, Joseph

1981 The Autographic Nature of the Dance. Journal of Aesthetic and Art Criticism 29 (4): 419-427.

Nikočević, Lidija

2003 Nematerijalni aspekti kulturne baštine i njihovo mesto u muzejima. Pogled etnologa. Informatica museologica 34 (3-4): 61-69.

Online publications

Ise Jing (http://www.wa-pedia.com/japan-guide/ise_jingu.shtml).

Shikinen sengu (http://www.isejingu.or.jp/english/sikinen/sikinen2.htm).

\section{USTVARJALCI, RAZISKOVALCI IN UPORABNIKI NESNOVNE KULTURNE DEDIŠČINE V LUČI DRŽAVNEGA SEZNAMA ŽIVE KULTURNE DEDIŠČINE}

$V$ slovenski etnologiji je pojem kulturna dediščina obravnavan na različne načine, ki kažejo ne toliko na značaj kulturne dediščine same, temveč na odnos raziskovalcev do nje. V celoti gledano bi labko rekli, da je odnos slovenskih raziskovalcev kulture do pojma kulturna dedišcina ambivalenten. V polpreteklem obdobju pojem kulturna dediščina ni bil vprašljiv: nanašal se je na vsebino t. $i$. ljudske kulture, ki vsebuje posebno značilnost, da je kot esenca v obliki vedenjskih vzorcev in zlasti nesnovnih prvin kulture trajno vpeta $v$ način življenja več rodov pripadnikov določene etnije, ljudstva ali naroda. Odtod sinonim "dediščna «: lastnina, ki jo prejmejo dediči od prednikov po njihovi smrti. V novejšem obdobju, ko so se na področju etnologije začela redefinirati epistemološka vprašanje vede (značilno postmoderno samo-spraševanje) in se je pozornost raziskovalcev usmerila bolj na sinhrone mreže pojavov kakor na njihovo genezo, je pojem kulturna dediščina naenkrat postal vprašljiv terminološko in problematiziran tudi kot predmet etnološkega preučevanja. 
Projekt registra nesnovne dedišcine Slovenije bi lahko bil podlaga za skupno razumevanje kulturne dediščine ne glede na različna epistemološka zaledja. Danes kulturna dediščina ni več niti eminentni predmet etnološkega preučevanja, niti orožje ali orodje narodnoobrambnega boja, danes je kulturna dedišcina $v$ svetovnem merilu priznan blue chip držav pristopnic h Konvenciji o varovanju nesnovne kulturne dediščine. Njen pomen danes ni odvisen samo od pogleda raziskovalcev, temvec tudi od motivacije in mnenja njenih ustvarjalcev ter uporabnikov. Nikoli prej kulturna dedišcina ni tako očitno predstavljala teme par excellence v humanističnih vedah, posebno v etnologiji, in priložnost za premislek o novih metodoloških podlagah za preučevanje kulturne dediščine. Je pa tudi priložnost za soglasno preoblikovanje širšega družbenega odnosa do kulturne dediščine kot bistvenega državnega podsistema kulture. K temu nas navajajo tudi druge Unescove konvencije, npr. Splošna deklaracija o kulturni raznolikosti (Universal Declaration of Cultural Diversity, 2001) in Konvencija o varovanju in spodbujanju raznolikosti kulturnih izrazov (Convention on the Protection and Promotion of the Diversity of Cultural Expressions, 2005), ki bistveno dopolnjujeta Konvencijo o varovanju nesnovne kulturne dediščine in ji dajeta veliko širši smisel in pomen, kakor ga imata zgolj nacionalni register in Unescov reprezentativni seznam.

Assoc. Prof. Dr. Naško Križnar, research advisor, ZRC SAZU Institute of Slovenian Ethnology, Novi trg 2, SI-1000 Ljubljana, Slovenia, nasko@zrc-sazu.si 